\title{
Creating an Eco-Sustainable Community: the Role of Zakat
}

\author{
Mohd. Ma'sum Billah \\ King Abdul Aziz University, Kingdom of Saudi Arabia
}

\begin{abstract}
According to Saud (1988) and Shad (1986), the institution of Zakat, is a divine obligatory sort of taxation acting as the most effective measure in upgrading the financial condition of the destitute. This institution strives to achieve objectives, which are broader in nature. This is because, not only does it aim at providing the society with financial security, but it also, as a whole, inculcates moral, social and spiritual values in each individual. In view of the institution of Zakat aiming at achieving broader objectives, this research therefore, seeks to prove that the institution of Zakat may not only form the basis of today's modern social security system, but also brings some other benefits to the society. The whole research however, is divided into several sub-sections besides a conclusion. It therefore, presents the foundation of the institution of Zakat followed by the evaluation of whether the institution of Zakat can provide a meaningful social security along with a justification that, the institution of Zakat is capable of providing a result oriented alternative to the modern social security system.
\end{abstract}

Keywords: Zakat, poverty eradication, sustainability, social security

JEL Classification Code: E62, H21,P51

\section{INTRODUCTION}

\section{Socio-economic understanding of Zakat}

Zakat could well be defined as one of the five tenets of Islamic teachings (Muhammad, 1993) which appears in the form of an obligatory tax (Saud, 1988) aimed at purifying a person's soul and wealth in establishing social justice in the society (Muhammad, 1993). Mannan (1970) argued this Islamic institution could be regarded as one of the principal threats to the root of today's capitalism Zakat is not only a form of charity but also compulsory tax collected from those who are rich and wealthy, and distributed among the right recipients as described in the Holy Qur'an. The principal objectives of Zakat are not only to reduce the rate of poverty in the society, but it simultaneously acts as a means of purifying one's soul and wealth. It is however, unfortunate that, the notion of Zakat is often misunderstood by the people who often regard it as to be only a mean of charity given out by the rich to the poor and the needy. The reality of the application of this institution could be summed up as follows:

- Apart from being charitable act, Zakat is also a compulsory tax imposed on the rich and wealthy at the rate varying from $25 \%$ to $20 \%$.

- It does not only provide financial assistance for the needy, but also purifies one's soul so as to make it closer to Allah $(S W T)$ and also purifies one's property and wealth so as to eliminate from one any sense of selfishness.

The scope of Zakat should not be narrowly interpreted today, relying only on 
the items specified and mentioned during the time of the Prophet $(S A W)$. In the early Islamic period, the idea of levying Zakat was on an annual savings of a prescribed amount $^{1}$, after deducting self and family maintenance and settlement of one's debts. Since, the nation of 'Zakatable property' was previously understood as an annual savings of a prescribed amount, it is only fair, in the context of today's contemporary society, to give a broader interpretation to the word, in the light of the Islamic doctrine of Masalih alMursalah (public interest), in order to enable us to apply the institution of Zakat in a more practical manner, towards providing a solution to the problems faced by the destitute in today's society. Thus, 'Zakatable wealth' of today should also include any annual savings, which the amount is prescribed by the Shari'ah ${ }^{2}$, be it in the form of currency or other forms of income or profits, made up from any business or other types of legal transactions.

The reimbursement of Zakat should also not be narrowly interpreted to be a mere act of charity, which means to help the beggars only. Broadly speaking, Zakat is an institution aimed at eradicating poverty by providing financial protection to the poor, the needy, the old and the weak, the unemployed, the disabled, the widows and so on, regardless of whether they asked for it or not. The fact is that, Allah (SWT) has determined that, in everyone's, wealth there is a portion for the people of the above classes. Allah (SWT) says to the effect:

"And in their wealth and
possession, the right of (needy),
him who asked and him who (for
some reason) was deprived ".
(QS. Ad-Dhariyat: 51)

\footnotetext{
${ }^{1}$ Also included in 'Zakatable properties' are gold, silver, animal, agricultural products, etc.

${ }^{2}$ The annual savings is made after deducting one's self and family maintenance and settlement of debts from one's income or property.
}

According to Qudama in I.Doi (1990) there is also another most common misconception of the word 'Zakat' among Muslims, that Zakat is being Divinely sanctioned for the Muslims only, while rendering the non-Muslims ineligible to enjoy any benefits of the Zakat institution. This is not so. Responding to this misconception, there are many Scholars who have accepted the idea that, the institution of Zakat is meant to be for both the Muslims and also the non-Muslims alike. This concept is further acknowledged by $A b u$ Ja'far Mohd. B. Jarir al-Tabari (Al-Tabari in I. Doi, 1990). Based on these arguments, it is hence a hypothetical solution that, Zakat provides the most practical solution to the problems faced by the poor and the needy in the contemporary society, as it protects each and every member of the society, regardless of difference in religious beliefs. It is very clear by the decree of Allah (SWT), whereby the recipients of Zakat need not to be Muslims alone ${ }^{3}$. Mannan (1970), thus, further clarified it as follows:

"Zakat acts as a unique measure
provided by Islam to abolish
poverty from the society by
making the rich live to the social
responsibilities they have. In the
economic sphere, Zakat prevents
the morbid accumulation of
wealth in a few hands and to
defuse it before it assumes
threatening proportions in the
hands of its possessors, as it is a
compulsory contribution of the
Muslims to the State Exchequer"

Sources of Zakat fund

It is undoubtedly submitted that, Zakat in its capacity may play its role in providing social and spiritual security in the

\footnotetext{
${ }^{3}$ The words Fuqara and Masakin at QS. AtTaubah: 60 which do include any needy and destitute regardless of one's religion.
} 
contemporary society, a brief analysis is made on the sources of Zakat fund. Thus the sources are namely on: self-assessment (al-Fitr), income over commercial businesses, savings, shares, employees provident fund, gold and silver, wealth, asset and property, agro-products, cattle and buried treasure.

Prior to the full implementation of Zakat, it is of utmost importance to ensure that, the sources for its fund are of tradable value and are Zakatable in nature, due to the rapid economic growth in contemporary society. In order to arrive at a determination whether the goods and properties are indeed Zakatable in nature (i.e. able to be used as a legal Zakat fund), it is important to apply, inter alia: the tradable test, which must be conducted in light of the Islamic principles of Qiyas (analogy) and Masalih al-Mursalah (public interest) so as to come up with more practical solutions on the test of tradability of the goods and properties. ${ }^{4}$ This is to enable the society to obtain maximum benefit from Zakat in ways recognized by Shari'ah. Hence, in order to determine whether the goods or properties used as the fund are indeed tradable and Zakatable, the following three-fold tradable test may be applied:

The goods or properties to be Zakatable must be in the form of additional goods, properties or profits after deducting one's self expenditures, family maintenance and settlement of debts. The goods or properties should be Zakatable on manual basis. The goods or properties to be Zakatable must reach a certain amount determined by Shari'ah.

Although, the modern social security system creates its fund from inter alia, taxes imposed on financially able citizens, ${ }^{5}$ and the Islamic institution of

Goods and properties here also include savings, products and so on.

${ }^{5}$ Besides the mandatory taxes imposed, the modern social security scheme also derives its fund from Contributory Benefits scheme which sources come
Zakat on the other hand, also creates its fund from mandatory taxes imposed on the tradable goods and properties ${ }^{6}$ the fact is that, Zakat still presents the society with a more ideal and practical solution compared to the modern system. This is because Zakat is not only a mere physical act of paying taxes by able persons, but it goes beyond that limit, as we find that it is also an act sanctioned by Allah (SWT) Himself, embodying spiritual, moral and educational elements. Whereas, the modern social security system offers only material assistance to the needy public, the institution of Zakat not only confers material assistance, but also contains spiritual moral and educational benefits.

After carefully digesting the two points already forwarded, let us see the proposed Zakatable goods in the contemporary world: Gold, silver (Saad, n.d.) and diamond: All sorts of monetary savings, which are derived from salary (Muhammad, 1993), premiums obtained from legal transactions and other sources: Assets and capitals of any company or business firms: Stocks and shares: Animals (Saad, n.d.): Any business license (Saad, n.d.): Hoarding articles or properties (Saad, n.d.): Agricultural products such as paddy, palm oil, cocoa, etc. ${ }^{7}$ Wealth obtained from mine such as tin, petrol, natural gas, and so on (Aliyu, n.d.).

\section{Underlying objectives of Zakat}

Al-Harran (1993) argued every injunction, which had been revealed by Allah (SWT) must have its own rationale and objectives. Hence, as regards to the institution of Zakat, Allah (SWT) has sanctioned it with the aim of providing social security for the poor and the needy in the society, and to

from willful contributions made by employers and employees.

${ }^{6}$ Although, the fund of Zakat is from mandatory taxes determined by Allah (SWT), it is also impliedly and simultaneously accepts willful contributions from the public. 
develop a balanced economic growth as well as to become the act of spiritual purity and development. The principal objectives of Zakat, in other words, could be summed up as follows: It is an act of purifying one's soul, by enabling one to become closer to Allah (SWT). It is thus justified in the Holy Qur'an when Allah (SWT) says to the following effect:

"... But it is righteousness ... to
spend of your substance ... for
your kin, for orphans, for the
needy, for the wayfarer, for
beggars and for the ransom of
captives... and practice regular
charity (Zakat)..."

(QS. Al-Baqarah: 177)

It is also meant to be an act of protecting the poor and the needy from any type of financial and material constraints. Mannan (1970) said that in other words, it strongly opposes the system of capitalism which means, it does not allow one to practice the habit of hoarding goods and wealth. Allah (SWT) has indeed warned people against any act of capitalism in the following sanction:

"Woe to every scandalmonger
and backbiters, who piled up
wealth and layeth it by. Thinking
that his wealth would make him
last forever. By no means he will
be sure to be thrown in to that
which breaks to pieces. And what
will explain to you that which
break to pieces? (It is) fine of
(the wrath of) Allah (SWT)
kindled (to a blaze). The which
doth mount (right) to the hearts.
It shall be made into a vault over
them. In columns outstretched?"
(QS. Al-Humazah: 1-9)

Such hoarding attitude of one's wealth is against the rules of Allah (SWT) and it surely deprives the poor and destitute from their actual rights. It is thus ruled out by Allah (SWT) as follows:

\begin{abstract}
"And in their wealth and possessions (was remembered) the right of the (needy). Him who asked and him who (for reasons) was prevented (from asking)" (QS. Adh-Dhariyat: 19)
\end{abstract}

It does not only benefit the poor but also the rich. According to El-Gouri (1982), the poor and the destitute would benefit from the financial and material assistance obtained from the rich, while the rich and wealthy will be handsomely rewarded by Allah $(S W T)$ in the hereafter for their act of obedience to Allah (SWT). It also plays a vital role in the progress of the spiritual aspect, economy and also technology in the society, bearing in mind that, this Islamic institution of Zakat benefits both the Muslims and the nonMuslims. Dr. R.R. Marett views that, the "real progress is in charity". Aldous Hoxley, meanwhile, observes that, "technological advance" will become useless without the "progress in charity". While Zakat functions as a means to eradicate poverty in the society, it also simultaneously molds the individuals into responsible and caring persons, who are always ready to help the poor and those who are unfortunate (Mannan, 1970).

At the same time, the institution of Zakat inculcates the spirit of brotherhood (Saud, 1988) in upholding social solidarity in the society (Islahi, 1933). It, at the same time, ensures an ideal sustainable social security for the poor, the needy, the old, the disabled, and other unfortunate individuals in the society regardless, of their religious beliefs, languages, races and so on. Finally, the Islamic institution of Zakat also creates creative individuals who are non-materialistic, self-sufficient and always grateful for the bounties of Allah $(S W T)$, enabling them to experience and enjoy vast spiritual development, social solidarity and also material prosperity (Islahi, 1933). 


\section{Socio-economic impact of Zakat}

As we have discussed earlier, the institution Zakat does not only provide the basis for social security but also plays many other important roles in the society. The fundamental roles played by Zakat, however, could be itemized as some points.

It provides the society with soul and wealth purity (Muhammad, 1993) developing the moral aspect, which mold the rich into being responsible and caring about the poor (Mannan, 1970). At the same time developing the spirit of brotherhood and cooperation based on goodwill in the society (Islahi, 1933). Moreover, it benefits the rich and the poor alike, whereby the rich will be rewarded by Allah (SWT) in the hereafter (El-Gourt, n.d.) the poor will be thankful for the material assistance rendered to them under the sanction of Allah (SWT) (Islahi, 1933). It also plays a vital role in providing a sustainable social security scheme in the following ways:

- By providing material assistance for the poor, the needy and the destitute (QS. AtTaubah: 60) in the society in order to fulfill their material needs, and enabling them to be self-reliant.

- By catering the required assistance in the circumstances of unemployment, insufficient medical expenses, for the old, the disabled and the handicapped, as well as inadequacies to maintain one's life, for widows and children with no parents: and so on, on the basis of needy test.

- By helping other members of the society who might not be originally poor materially and financially, but nevertheless, unexpectedly facing material or financial constraints due to certain unexpected and unfortunate happenings, such as having financial difficulties during traveling, and so on (QS. At-Taubah: 60).

The institution of Zakat also relieves a person from the burden of insolvency should he or she is unable to settle the debts (QS. At-Taubah: 60). Zakat indeed also plays an extremely important role in protecting and helping those who are sacrificing themselves in the path of Islam, in order to uphold the System (Deen) of Allah (SWT) in this earth (The Holy Qurán in Ali, n.d). After seeing the vital roles played by Zakat in the society, it is hence easy to point out its significance as summarized in points below.

According to Al-Harran (1993), the institution of Zakat benefits both the rich and the poor. Mannan (1970) said that it creates members of the society with responsible and caring attitude. It inculcates strong spirit of brotherhood, goodwill, cooperation and tolerance in the society (Islahi, 1933). It also provides the society with purification of soul and wealth (Muhammad, 1993). Zakat provides material and financial security for the poor and other unfortunate members of the society (QS. At-Taubah: 60). It provides both the Muslims and nonMuslims with material and financial protections (I. Doi, 1990). It also seeks to relieve an insolvent from his unsettled debts (QS. At-Taubah: 60). Likewise, it helps those who are sacrificing themselves in the cause of upholding the religion of Allah (SWT) (The Holy Qurán in Ali, n.d).

\section{SCOPE OF FUQARA (POOR) AND MASAKIN (DESTITUTE)}

We have seen earlier how the modern social security system derives a two-fold solution to help the poor and the needy in the society, i.e. through the contributorybased scheme, whose fund is obtained by way of willful contributions by the employers and the employees, and the non-contributory-based scheme, whose fund is collected from the state tax revenues. We have also seen how the institution of Zakat derives one-fold method in helping the poor and the needy on non-contributory based scheme, whereby the fund is derived from obligatory taxes paid by the able citizens. 
The issue to be determined before us now is, whether the type of beneficiaries prescribed by the modern social security system (such as the poor, the disabled, the handicapped and so on) are within the ambit of the Fuqara and Masakin as mentioned in the Holy Qur'an? (QS. At-Taubah: 60) The answer is, yes, the words Fuqara and Masakin do cover all the beneficiaries prescribed under the non-contributory based scheme of the modern social security system, based on the Islamic doctrines of Qiyas and Masalih al-Mursalah. It is thus, further justified as follows:

The beneficiaries under the noncontributory-based scheme prescribed by modern system are determined on the basis of the 'needy test', while the meaning of the words Fuqara and Masakin are also based on the 'needy test' i.e. the beneficiaries of the fund must indeed be based on the need of financial or material assistance. In fact, the broad interpretations of the two words include not only those beneficiaries prescribed by the modern scheme but also those who are not prescribed by it, but it includes any person so long as one falls within the definition of needy. Hence, it is only natural to deduce from it the notion that the definitions of beneficiaries under the modern social security system falls within the broad interpretation of the words Fuqara and Masakin in the Holy Qur'an at 9:60. The broad interpretation of the words Fuqara and Masakin are also shared by some Islamic dictionaries, for example, Abdullah Yusof Ali has interpreted the word Miskin as 'needy', and Faqiris as someone who is in financial need' (QS. At-Taubah: 60).

Bassam Sulaiman also shares the same view as Abdullah Yusuf Ali on the interpretations of the definition of the words Faqir and Miskin (Abughosh, et. al, 1993). The dictionary in Islam on the other hand, defines the word Faqir as the 'poor' and Miskin as one who has no property whatsoever (Hughes, 1985). Another encyclopedia defines the word Faqir as a beggar, a dependent or the one who is in need as opposed to Ghani or a rich (Gibb et all, 1974), while another encyclopedia of Islam defines the word Miskin as the poor, the most needy, miserable or the person whom it is an obligation for believers to support (Houtsma, 1936). Therefore, the broad definitions and interpretations of the word Faqir and Miskin given by the above dictionaries and encyclopedias of Islam further enhance the view that, the ambits of both words cover the poor and the needy, who not only cover the prescribed beneficiaries under the modern system, but also other beneficiaries besides it. Act that both Faqir (the poor) and Miskin include anyone who is in need of material or financial assistance (which of course includes those beneficiaries prescribed by the modern social security system) is further strengthened by the fact that, even the modern English dictionaries give broad interpretations of both words. For instance, The New Shorter Oxford English Dictionary defines a 'poor' as a person who is unfortunate, needy, destitute or indigent or the one who is lacking or procure comforts of necessities of life, or the one who is having less than is wanted or expected (Brown, 1993). The same dictionary also defines the word 'needy' as the one who is 'poor', destitute or a person without necessities (Brown, 1993). Meanwhile, Webster's New Twentieth Century Dictionary defines 'poor' as the one who is poor, or needy or indigent, or money less or insolvent, lacking pleasure or comfort. It also defines 'poor as the one who is lacking material possessions or having little or no means to support oneself (Webster, 1983). The same dictionary defines the word 'needy' as the one who is poor or not having enough to keep up an adequate standard of living (Webster, 1983). Based on all these logical arguments, it is of no surprise that we have finally came to the conclusion that, the words Fuqara and Masakin as mentioned 
by Allah (SWT) in the Holy Qur'an at 9:60 indeed carry broad interpretations, based on the doctrines of Qiyas and Masalih alMursalah, so as to include anyone, who is in need of financial or material assistance, which of course include also the prescribed beneficiaries determined by the modern social security system.

\section{APPLICATION OF ZAKAT AS TO SOCIO-ECONOMIC AND CULTURAL REALITY}

It has already been acknowledged in the light of our earlier analysis that, the institution of Zakat provides material and financial assistance for the modern needy society as a whole, regardless of one's religious belief, color, race or even sex. This phenomenon presents us with the clear idea that Zakat could act as an ideal solution towards helping the poor and the needy in the modern world of today. The next question to be answered is, how can we turn this fact into a reality? Hence, in materializing this noble aim, the following logical methodologies could be adopted:

\section{Inculcation of the significance of Zakat}

It has already been realized that Zakat contains more significance towards not only the material aspect, but also social, moral and spiritual aspects of the society as compared to what is offered under the modern social security system. Zakat, as we have already seen, also extends its role to each individual in the society who is poor and needy, regardless of one's sex, religion, race, color or whatsoever reason may be. Hence, in order to educate and inculcate such phenomenon and ideas of Islamic institution of the Zakat, exhibitions and seminar dialogues could be held for the public and government officials around the globe. This effort must always be accompanied by publishing of writings, articles and journals in propagating the idea and significance of the institution of Zakat in the contemporary society.
Correction of the misconceptions about Zakat

The well-known misconception about the institution of Zakat, which portrays it as an institution for beggars and low-class people should be rebutted in upholding that Zakat is a form of social security provided for those who are poor and in order to transform them into self-reliant. Such material and financial assistance is indeed a duty and an obligation upon those who are able materially and financially, as it is aimed at assisting and accommodating these unfortunate members of the society, making them welcomed and not to degrade their personalities.

Pragmatic application of the rules of Zakat based on the Islamic principles

It is undeniable truth that the society is always developing and changing with culture, thinking and so on. Hence, in sustaining the development and changes, there is a need to apply the rules of Zakat in the light of the Islamic concept of Siasah al-Shari'ah' which stresses the application of all Islamic principles based on the doctrine of Qiyas (analogy) and Masalih al-Mursalah (public interest). Such move is needed in order to ensure a successful application of the Islamic rules of Zakat based on the doctrine of Siasah al-Shari'ah, in order to provide financial and material protection for the poor, the needy and the unfortunate in today's society, which inter alia, surely eliminates one's hardship while securing a comfortable life for all. It is indeed in line with Qur'anic principles where Allah (SWT) says:

"... God (SWT) intends every facility for you: He does not want to put you in difficulties..."

(QS. At-Taubah: 60) 


\section{CONTEMPORARY HUMANITARIAN CONCERN}

Even though, it is an undeniable fact that, the modern humanitarian paradigm is trying to help the poor and the needy in the society to live comfortably and with dignity, there are still some aspects of it, which may be questioned: First of all, the modern security system fails to cater for the insolvent with providing financial assistance to settle their debts.

Secondly, even though it helps the unemployed by offering them financial assistance, such a move is unwise as it might turn them into lazy citizens, who would depend solely on assistance without having any kind of urge to solve their own plight. Hence, instead of providing them with such assistance, it may be better to provide them with a short-term loan to allow them to open their own businesses, which will of course be more beneficial to the unemployed, rather than giving them financial aids. Thirdly, there is also no financial assistance available under this modern system for the needy wayfarers, who are unable to maintain their costs for the rest of the journey.

\section{ZAKAT IS AN ALTERNATIVE TO THE MODERN HUMANITARIAN CONCERN}

After scrutinizing both systems above, we have seen the similarities and differences on both systems. Hence, for the purpose of further analysis between the two systems, let us make a comparative evaluation on the programs designed by both systems: The modern social security system provides a two-fold solution in helping the poor and the needy in the society. The two-fold solution is classified as the contributory-based scheme (whose fund is derived from willful contribution from employers and employees): the noncontributory based scheme (whose fund is created from the State's tax revenues).
The institution of Zakat on the other hand, offers a one-fold scheme, which is broader in nature. This scheme is non-contributory one, in which the needy people of the society are to be helped out by the compulsory tax (Zakat) payable by the rich. In other words, the needy people who are benefited by the Zakat are on noncontributory basis under the principles of Zakat. ${ }^{8}$ The type of beneficiaries described by the modern social system such as the poor, the disable, the old, the handicapped and so on are (QS. At-Taubah: 60) also approved by the Shari'ah in the light of the institution of Zakat under the broad meaning of Fuqara and Masakin, which means the 'poor' and the 'needy'. Such broad interpretation of the above two words is based on the doctrines of Qiyas (analogy) and Masalih al-Mursalah (public interest) and will be dealt with in the forthcoming section.

The dissimilarities between both the modern and the Islamic systems as we have seen so far, are undeniable. However, it must always be remembered that, the Islamic institution of Zakat offers a much wider role and scope in its application, making it to be the most suitable and practical method in providing the poor and the needy with a proper social security. In other words, among the things offered by Zakat, which are not available under the modern system are: The Zakat fund helps an insolvent to settle his debts provided that, the insolvent does have sufficient financial ability to settle the debt. As al-Tabari pointed out that, the insolvent is the indebted without extravagance. According to Qardhawi, the rule is required to pay his debt from the treasury (Zakat). It also sets up a scheme to provide necessary financial aid for the wayfarer who unexpectedly faces financial risk regardless of rich or poor. ${ }^{9}$ By QS. At-

\footnotetext{
${ }^{8}$ See QS. At-Taubah: 90, where all the identified beneficiaries are noncontributory based.

${ }^{9}$ Note that the interpretation of the word Masakin is very broad.
} 
Taubah: 90, the Zakat fund extends its services to those needy people who are striving in the path of Allah (SWT). The people who are striving in the path of Allah (SWT) include fellow students who are seeking knowledge, as well as those who sacrifice themselves, their property, energy and time in establishing the deen (religion) of Allah (SWT) in any manner. Zakat also relieves those who are under financial bond. In the contemporary world, those who are under this category included detainees and hostages who could only be released by their captors on the payment of certain amount of ransom. It also provides reasonable wages for those who are involved in collecting the Zakat.

Zakat also provides protection for Muslims and non-Muslims alike (I. Doi, 1990), rendering it to be one of the most equitable means of social security. As Abdur Rahman I. Doi quotes, in support of this view that when Sayyedana Umar (r.a) was traveling to Syria and saw a needy Christians he (r.a.) ordered that, they should be looked after by the Zakat fund (Al-Baladhuri, n.d.). The institution of Zakat also creates a caring society (Mannan, 1970), inculcating the strong spirit of brotherhood, goodwill, tolerance and cooperation among the members in the society (Muhammad, 1993). Last but not least, this Islamic institution also provides the society with wealth and spiritual purification (Muhammad, 1993).

\section{ZAKAT IS AN ABLE ALTERNATIVE TO THE MODERN SOCIAL SECURITY SYSTEM}

Under the contributory-based scheme of modern social security system, among the benefits available are retirement pensions, widows' benefits, invalidity benefits, unemployment benefits and sickness benefits. This scheme is operated on the basis of willful financial contributions by the employers and the employees, while it works for the designed-people on the needy test basis. Although, Zakat is the collection of compulsory tax paid by those who are financially able, it is spent for the security of needy people in the society. Since beneficiaries designed under the contributory-based of modern social security system are on needy test basis hence, it is obvious that the Zakat could undoubtedly provide a social security for those needy people on the basis of needy test. The only difference here is that, those needy are helped out under the modern social security system upon the contribution basis, whereas under the principles of Zakat they are helped out on non-contribution basis.

Here, I would like to analyze with a justification that the beneficiaries under the contributory-based scheme of the modern social security system could be catered by the institution of Zakat on the needy test basis. The justifications are as follows: As regards to the concept of retirement pension, it was even practiced long time ago during the era of the Caliph Umar (r.a) who set up a special Dewan or department to manage the retirement pension. He even once ordered the government to pay regular pensions to both Muslims and non-Muslims (AlBaladhuri, n.d.). Because, retired is a jobless with no income, hence is usually considered as a needy. Thus, those who are considered as a needy surely deserve Zakat. As regards the widow's benefits, it is one of the great virtues to look after the welfare of the widows as the Holy Prophet (SAW) once said to the effect:

"The one who looks after and works for a widow and for a poor person is like a warrior fighting for Allah's (SWT) or like a person who fasts during the day and prays all the night..." (Sahih al-Bukhari in Khan, 1983).

Thus, such welfare is also on the needy test. An invalidity benefit is for those beneficiaries who are unable to work and earn their necessities due to 
sickness and such a concept is also in harmony with the commandments of Allah (SWT) in helping the needy, as $\mathrm{He}$ $(S W T)$ narrated to the following effect:

"And in their wealth and possession, the right of (needy), him who asked and him who (for some reason) was deprived." (QS. Adh-Dhariyat: 19)

Unemployment benefits are meant for those who are unemployed due to crisis in the job market or under qualification. Islam has indeed indicated that, it is a moral obligation to help those who are unemployed and face difficulties as the result of that phenomenon. The Holy Prophet (SAW) said to the effect:

"Whoever solves the worldly
difficulties of a believer, Allah
(SWT) will remove from him one
of the grieves of the Day of
Judgment. Whosoever alleviates
(the lot of) a needy person, Allah
(SWT) will alleviate (his lot) in
this world and the next ..." (QS.
Adh-Dhariyat: 19).

There are some situations whereby some people are unable to maintain themselves as well as their families due to unexpected sickness, which hamper their ability to earn their basic necessities and needs. As such, Islam also encourages the people to help these types of needy people as we find the Prophet (SAW) saying to the following effect in one of his traditions:

“... Whosoever alleviates (the lot of) a needy person, Allah (SWT) will alleviate (his lot) in this world and the next...."

Furthermore, Shaikh Shamsuddin Ramli, in support of his view said that, in the case of a person facing hardship due to sickness or any other cause, which results him in becoming poor and needy. Such a person regardless of religion should be assisted, not only by providing cloth and food, but also with all the necessary aids of medical treatment (Ramli, $1292 \mathrm{SH}$ ).

On the other hand, under the noncontributory based scheme of the modern social security system, the beneficiaries may be helped based on the fund financed by the compulsory tax imposed on those who are materially and financially able. Indeed, both the modern security system and the Islamic system of Zakat offer such scheme. The only difference that exist between the two systems is that, under the modern system the beneficiaries have been 'specified', whereas the institution of Zakat covers unlimited category of beneficiaries under the broad application of the words Fuqara and Masakin upon the application of the needy test, which of course, includes not only the beneficiaries specified under the modern social security system, but also any person of the society so long as he/she falls under the meaning of needy and destitute, regardless of one's religion, race, gender or even color.

A closer look at the application of the notion of the institution of Zakat will reveal that, it besides acknowledging the limited recipients specified by the modern system, also extends its helping hand to the other type of needy people living in the society. For instance, the institution of Zakat does not oppose the material and financial assistance for the under aged children under the modern social security system as they are considered among the needy in the society. The Holy Prophet (SAW) in fact, encouraged the people to look after the needy children when $\mathrm{He}$ (SAW) said to the effect:

\section{"I and the person who looks after an (needy) orphan and provides for him will be in paradise." (Sahih al-Bukhari in Khan, 1983)}

The under aged children are income less and thus, they are considered as a needy to maintain themselves sufficiently. The Holy Prophet (SAW) 
emphasized to look after any need people living in the society. He (SAW) said to the effect:

"The one who looks after and works for ... (the) poor person is like a warrior fighting for Allah's (SWT) cause..." (Sahih alBukhari in Khan, 1983)

The Islamic institutions of Zakat also shares the same notion with the modern social security system that, single parents (such as those who lost their spouses through death or divorce) should be financially and materially helped out, as the Holy Prophet (SAW) said to the effect in one of the traditions that:

"The one who looks after and works for a widow and for poor is like a warrior fighting for the cause of Allah (SWT)" (Sahih alBukhari in Khan, 1983).

As far as one's disability is concerned, Islam has also encouraged fellow human beings to look after those who are helpless and disabled in order to sustain a meaningful life. In Islam, it has always been a responsibility of the able person to remove all hardships from the disabled and helpless, as we find the Prophet (SAW) mentioned to the effect in the coming tradition:

"Whosoever removes a worldly grief from a believer, Allah (SWT) will remove from him one of the grieves of the Day of Judgment. Whosoever alleviates (it from) a needy person, Allah (SWT) will alleviate (his lot) in this world and the next.... Allah (SWT) will aid a servant so long as his servant aids his brothers..." (Sahih al-Bukhari in Khan, 1983)

Zakat also shares the policy with the modern social security system that, financial and material assistance to the income supplement should also be reserved for a person whose income is low and insufficient to support his own family. Indeed, Islam regards it as a duty, which has to be shouldered by those who are financially and materially secured. The Prophet (SAW) expressed in one of the traditions that one who removes the grief of another will obtain the help from Allah (SWT). The very idea of providing free health service for those who are unable to pay for medical and health treatments (such as by providing medicines, subsidizing in treatments, sick-beds accommodations at clinics and hospitals, food for those who are hospitalized, etc.) is very much in line with Islamic principles, teachings and belief. The institutions of Zakat, in fact, is also in favor of providing even more extensive assistance in this regard, by providing total exclusion from medical expenses and so on. Moreover, in the view of Shaikh Shamsuddin, both the Muslims and the non-Muslims are entitled to any kind of assistance under Zakat (Ramli, 1292). Other types of beneficiaries under the modern social security system who are entitled to obtain benefits such as attendance allowance, mobility allowance, invalid care allowance, housing benefits, social funds and so on are indeed recognized under the Islamic institutions of Zakat.

\section{MULTI-RELIGION DESTITUTE AND THE ROLE OF ZAKAT}

The modern social system was invented based on conventional thought in order to cater for the poor and the needy in the society, regardless of their race and religion. The question here is, can Zakat and its fund offer similar protection to the poor and the destitute in today's modern society, which is multi-racial and multireligious?

We have already seen that Zakat in practice is a compulsory tax, accumulated 
for those whose income and property has reached to a certain amount. However, as regards to the question whether it is able to cater for multi-religion society or not, the ulama or Islamic jurists have mixed views on it. Some of them are of the opinion that, Zakat is a compulsory tax collected from Muslims and it is therefore, should provide social security for Muslims only (Qudama in Abdur Rahman, 1990). However, the majority of the Ulama are of the view that, Zakat is an Islamic institution, which not only provides social security for the Muslims, but also for the non-Muslims who are poor and needy, regardless of differences in religion, color or sex. This view is indeed justified by the following evidences:

The words of Faqir and Miskin mentioned in verse 9:60 are 'Am (general) in nature so as to include any 'poor' or 'needy' person be them Muslims or nonMuslims. It is indeed justified by the case when the second Caliph of Islam, Sayyedana Umar (r.a.) once saw Jew begging from other people due to old age and financial constrain. $\mathrm{He}$ (r.a), upon witnessing this situation recited the Holy verse (QS. At-Taubah: 60) which means:

"undoubtedly the Zakat is for the poor and the destitute" (I.Doi, 1990)

$\mathrm{He}$ (r.a.) then said that, the recipients of Zakat must not necessarily be Muslims only, but should also be extended to the non-Muslims (Abu Yusof, n.d.) Once, the second Caliph (r.a.), in another occasion, saw some Christian lepers. He (r.a.) ordered that they should be given Zakat and be looked after by the property (Al-Baladhuri, n.d.). During the period of Sayyedana Abu Bakar (r.a.) the first Caliph, Khalid ibnWalid (r.a) wrote in respect of the Christian inhabitants of alHira in Iraq, saying that:

"Any old man incapable of work or anyone who has suffered from any calamity, or any person who was rich and suddenly became a pauper asking for charity from his people, Jizyah must not be collected from him. He and his family, as the contrary, should be maintained through the Baitul Mal of Muslims."

(Abu Yusof in I.Doi, 1990)

The First and Second Caliph (r.a.) of Islam had also established an organization for social security, which functioned for the betterment of the needy, both Muslims and the non-Muslims. (I. Doi, 1990) Imam Zufar (r.a.) ruled that, the non-Muslims who are needy and poor should also be helped out of the Zakat fund, which may bring them closer to Muslims (I.Doi, 1990) The Maliki and Zaidi Schools of law are also of the opinion that, the non-Muslims who are poor and needy should also be given the opportunity to share the benefits of the Zakat fund, so as to soften their hearts in order to become more friendly and closer to Muslims (Ibnu Qudama in I.Doi, 1990). Al-Nawawi also expressed that it is a common obligation to help the needy and feed the hungry (Al-Nawawi in I.Doi, 1990) regardless of their religion. Ramli, meanwhile, acknowledged that:

"The non-Muslims are like
Muslims when it comes to
relieving them from their
sufferings. It is essential for all
Muslims to remove any harm
coming to them. Apart from food
or clothing of the needy non-
Muslims, it is also Fardu Kifayah
to help them in the treatment of
their sickness and giving fees to
the doctors, and buying medicine,
etc." (Ramli, $1929 \mathrm{SH})$.

Abdur Rahman I. Doi accepts the view that, although the non-Muslims do not contribute to the Zakat fund they should be assisted by it (I. Doi, 1990). He went on to say that non-Muslims are 
indeed part and parcel of the Islamic State. Hence, it is the responsibility of the state to provide social security for all Muslims and non-Muslims alike (Ramli, 1929 SH). All the above-mentioned justifications prove that the Islamic institution of Zakat and its fund is able to provide a meaningful social security for all members of the society, regardless of their color, race, sex and religion. As long as one falls within the definition of needy and destitute he could be aided out by the institution of Zakat.

\section{INVESTMENT OF ZAKAT FUND}

It had been a traditional mind-set that, Zakat is a mandatory charity, which shall be given away to the recipients by having no objective of commercial gain or income generation. This mind-set might have ensured only a short-term achievement, despite the true divine objective of Zakat is among others is, to care about poverty eradication with a sustainable and longterm results. To meet the Divine objective of Zakat the mind-set of the managing authorities shall be shifted from traditional to reality. Enriching the Zakat fund by applying whatever legitimate mechanisms and strategies may create added opportunities for the poor with ecostability. Thus, investing of Zakat fund with securitization may not be a Shari'ah contradiction, rather the idea to be encouraged in view of expanding the scope of the humanitarian opportunities with sustainable and long-term goals.

The possibilities of investment of Zakat fund along with its possible model has recently been reemphasized by Prof Dr Mohammad Sahyabani in his presentation held at the Islamic Economics Institute, King Abdul Aziz University, Saudi Arabia (Sahyabani, 2016). But, only risk may be anticipated if case a deficit is encountered by the principal (Zakat fund) in the course of investment. Who shall take the responsibility? The state or the Zakat foundation or the project owner (investee)? And how should it be resolved? It is thus, recommended that, an investment of Zakat fund shall be securitized by a principal deficit risk policy (Islamic insurance) against any risk (deficit) if in case befall against the principal during the course of investment.

\section{LONG-TERM HUMANITARIAN PLAN FOR ZAKAT: A FURTHERANCE MODERN APPROACH}

As has been discussed earlier that, Zakat fund shall not be treated with a short-term objective, but a long-term strategic plan over the Zakat fund may truly lead to an achievement of sustainable goals and that is an ultimate objective of Zakat. There are five basic aspects of life to be satisfied as the natural right of all mankind regardless of one's religion, status or background. They are namely: economic stability, education, health care, shelter and free from debt. If those five aspects of a man are satisfied, is a primary success to the social security in any state. Thus, the Zakat fund can be planned strategically with long-term objective to achieve those five basic aspects for the poor and destitute, aiming at a good social security as follows:

\section{Cooperative micro-entrepreneurship}

Economic stability in creating cooperative micro-entrepreneurship among the selected poor and destitute by providing Qardul Hasan (benevolent loan) from the Zakat fund, which shall be refundable out of the income generated from the business. Such scheme may be granted for a period of five years to enable the entrepreneur becomes financially stable.

\section{Edu-cooperation}

Financial assistance may be awarded as a Qardul Hasan (benevolent loan) out of Zakat fund for the poor students, which shall be refundable out of the income 
generated only upon one's graduation. The objective of the refund is to enrich the Zakat fund to help strategically other helpless ones, which may ultimately contribute to a good bye to the poverties in the global environment.

\section{Group health care}

A group health care insurance scheme (takaful) may be designed for those of poor and destitute, in which the premium shall be payable out of the Zakat fund, aiming at opening an opportunity for the poor and helpless patients to enjoy with basic health care rights. This may eventually create a healthy society.

\section{Cooperative housing scheme}

Financing facility may be awarded as a Qardul Hasan (benevolent loan) out of the Zakat fund for the poor families to purchase a reasonable house in allowing them to enjoy with their basic right as to live in own shelter. This Qardul Hasan shall be refundable within an affordable duration. If in case the house owner fails to complete the refund because of his or her death or disablement, the legal heirs of the owner shall settle it or a mortgage takaful plan on the house may take care of it or the Zakat fund may issue a waiver note with forgiveness to the house owner.

\section{Immunity insolvency plan}

There are many poor people living in the society suffer with unsettled debt, resulting them to be declared bankrupt or to face other disastrous consequences. Zakat fund may provide financing facility as a Qardul Hasan (benevolent loan) for those of poor debtors or insolvents in relieving them from the unexpected suffering due to unsettlement of debt. The Qardul Hasan shall be refundable within an affordable period. If in case the borrower fails to complete the refund because of his or her death or disablement, the legal heirs of the borrower shall settle it or the Zakat fund may issue a waiver note with forgiveness to the borrower.

\section{CONCLUSION}

Finally, it is submitted that, the institution of Zakat is unique and is capable of providing practical and ideal solutions in its capacity as an able alternative to the modern social security by caring about least fortunate ones, regardless of one's religion, race, language, color, status and gender with no discrimination (QS. AlBaqarah: 185). The institutions of Zakat is a non-contributory based scheme by mandatory payment (alms) payable by those who are financially and materially able (sahebul maal), aimed at providing social security for the poor and the needy in the society with Divine concern (QS. Al-Hujurat: 11). The proper application and administration of Zakat does not only guarantee a meaningful social security and solidarity ${ }^{10}$ but also provides an alternative way out of today's most common threat of the capitalism (Saud, 1988).

\section{RECOMMENDATIONS}

Towards a result oriented implementation of Zakat in view of a better social security in today's reality, the followings are recommended:

1. It is important that, the institution of Zakat besides being able to provide for the needy with material and financial security, also contributes in one's socio-moral and spiritual achievement. This institution does not provide a meaningful social security for the Muslims only, but for non-Muslims too. It is thus timely to inculcate the value of Zakat with its significant results for the humanity through writings, talks, debates and views.

\footnotetext{
${ }^{10}$ Based on QS. At-Taubah: 60, the words Fuqara and Masakin refer to the 'poor' and the 'needy' in the society, regardless of their religion, race, sex, or color.
} 
2. The misconception that Zakat is an institution, which caters for the beggars and low class citizens, should be refuted. This is because, Zakat in the view of the Shari'ah is an obligatory alms imposed upon the materially and financially able persons, in helping the unfortunate ones (the poor and the needy) aiming at upgrading their lives based on the spirit of brotherhood. It is not meant to downgrade the position of the poor and the needy in the society. Moreover, the fund of Zakat should not be disbursed as a charity to the poor, but it should be utilized accordingly in upgrading the life of the needy while strengthening the spirit of brotherhood between the rich and the poor.

3. The administration and application of the rules of Zakat should be done on the basis of Siasah al-Shari'ah in an effort to meet the legitimate demands of the needy society. Such a move is aimed at ensuring that Zakat remains as the most ideal and practical solution for the society, by structuring it as a model for the social security system, benefiting all needy citizens, regardless of one's religion, race, color or gender.

Zakat may, with gradual effect, gain the recognition of the modern world as the most ideal and practical solution in helping the poor and the needy in the contemporary society. Such aspiration is not just based on the commandments of Allah (SWT), but also based on the fact that it may cater for each and every individual in the needy society, the Muslims and the non-Muslims alike, as justified earlier. Zakat operates on the divine concept of brotherhood aims at strengthening the unity of the nation. Furthermore, as its application is based on the principle of Siasah al-Shari'ah, it is not impossible to see the institution of Zakat emerges as the most ideal and practical solution in providing the contemporary society with a meaningful social security, accepted by all.

\section{REFERENCES}

Ali, A. Y.,The Holy Qur'an (eng, trans.)

Al-Tabari, Tafsir al-Tabari, Vol. 2, Cairo (n.d.).

Aliyu, C. U., (n.d.), "Fiqh al-Muamalat and the Need for Islamic Economies: A Clarification of Misconception", (ed.)

Al-Baladhuri, Kutub al-Buldah, (n.d.) al-Harran, S. A. S. (1993), Islamic Finance Partnership Finance, PelandukPublications, Malaysia

Abughosh, B. S., et. al. (1993), Glossary of Islamic Terminology, Taha Publishers Ltd. London.

Abu Yusof, Kitabul Kharaj (n.d.).

Al-Nawawi, Al-Minhaj (n.d.).

Brown, L. (1993), (ed) The New Shorter Oxford English Dictionary, Clarendon Press, Oxford.

El-Gouri, A.M. (1982), Riba, Islamic Law and Interest, (u.p.) Temple University.

Islahi, A.A (1993), "Islamic Distribution Scheme, A Concise Statement" (ed.) Dr. F.R. Faridi, et.al, in Journal of Studies, Vol. 5, No. 1.

Gibb, H.A.R. et. al. (1974), Shorter Encyclopedia of Islam, Netherlands.

Hughes, T. P. (1985),, Dictionary of Islam, London.IbnQudamah M. Q. alMadiri (1348 AH), Al-Mughni Cairo, Vol. 1

I.doi, A. R., (1990) Non-Muslims Under the Shari'ah, A.S. Noordeen, Kuala Lumpur

M. Th et. al, (1936) (eds), The Encyclopedia of Islam, London.

Muhammad, A.A (1993), Zakat and Rural Development in Malaysia, Berita Publishing, Kuala Lumpur.

Mannan, M. A. (1970), Islamic Economics, Theories and Practices, Sh. Muhammad Ashraf Publishers, Lahore.

Qardhawi, Yusuf. Fiqh al-Zakat, Vol.1 
Qudama, Ibn, (1348 AH), al-Mugghni, Cairo, Vol. 11.

Ramli, S. (1292 SH), Nihayatul Muhtajila Shahrul Minhaj, Bulaq,. Vol. 8 Sy 46.

Sahih al-Bukhari (Trans.) Khan, M. M. (1983), Vol. 111, Kazi Publications, Lahore.

Sahih Muslim as compiled in Al-Nawawi, (1985) Forty Hadith (Trans. Eng.) Ibrahim, E., IIFSO.

Saud, M.A (1988), Contemporary Zakat, Zakat and Research Foundation, Ohio.

Shad, A. R. (1986), Zakat and Ushr, Kazi Publications, Lahore.

Sixth Malaysian Plan. (1991-1995), Kuala Lumpur.
Sahyabani, M., "Zakatus Sanadiq alIstithmariyah", presented at the Islamic Economics Institute, King Abdul Aziz University, Saudi Arabia, November 02, 2016.

Webster, N. (1983), Webster's New Twentieth Century Dictionary of the English Language, Prentice Hall Press, New York.

Mohd. Ma'sum Billah

King Abdul Aziz University

Jeddah

Kingdom of Saudi Arabia

profdrmasumbillah@yahoo.com 